\title{
IMPLEMENTING CHILD-FRIENDLY TEACHING METHODS TO IMPROVE QUR'AN READING ABILITY
}

\section{Imam Fauji}

Fakultas Agama Islam, Universitas Muhammadiyah Sidoarjo

Jl. Mojopahit No.666 B, Sidowayah, Kabupaten Sidoarjo, Jawa Timur, Indonesia, 61271

Email: Imamuna.114@umsida.ac.id

\section{Eni Fariyatul Fahyuni*}

Fakultas Agama Islam, Universitas Muhammadiyah Sidoarjo

Jl. Mojopahit No.666 B, Sidowayah, Kabupaten Sidoarjo, Jawa Timur, Indonesia, 61271

*Email corresponding author: eni.fariyatul@umsida.ac.id

\author{
Abdul Muhid \\ Fakultas Psikologi dan Kesehatan, Universitas Islam Negeri (UIN) Sunan Ampel Surabaya \\ Jl. Ahmad Yani No.117, Kota Surabaya, Jawa Timur, Indonesia, 60237 \\ Email: abdulmuhid1975@gmail.com
}

\section{Zaki Nur Fahmawati}

Fakultas Psikologi dan Ilmu Pendidikan, Universitas Muhammadiyah Sidoarjo

Jl. Mojopahit No.666 B, Kabupaten Sidoarjo, Jawa Timur, Indonesia, 61271

Email: zakinurfahmawati@umsida.ac.id

Received: 03, 2020. Accepted: 06, 2020. Published: 06, 2020

\begin{abstract}
The Qur'an serve as guidance in Muslim life, it goes without saying that there is an obligation for parents to teach their children the ability to read the Islamic holy book. On the part of school institution, educators are expected to offer interesting teaching methods to read the Qur'an so that they have an ease to acquire the ability. This study was aimed at investigating the relationship between teaching methods and students' ability to read the Qur'an. This study applied an action research to explore practical problems and to find some solutions to the problems encountered. The research subjects were 283 students of class VII at SMPN (Sekolah Menengah Pertama Negeri/State Junior High School) 2 Porong. This study collected data through: survey, observation, and semistructured interviews. The findings show that students' ability to read the Qur'an can be categorized into four levels namely: Ibtidā 1, Ibtidā 2, Jayyid, and Jayyid Jiddan. Those four categories placed students based on their abilities in reading Qur'an. According to Pearson correlation, there was a significance value of $0.000<0.05$, which means there is a linear relationship between the teaching methods and the students' ability to read the Qur'an. Following this result, some methods of learning to read the Qur'an like Iqra, Tahqiq, Talaqqi Mushäfahah, and CMSA (Cara Mengaji Santri Aktif/an active way to read Qur'an for students) are in position to be applied in order to improve children's Qur'an reading abilities.
\end{abstract}

Keywords: Child-friendly School, Religious Character, Teaching Methods

\section{ABSTRAK}

Al-Qur'an berfungsi sebagai pedoman dalam kehidupan Muslim, tidak perlu dikatakan bahwa ada kewajiban bagi orang tua untuk mengajar anak-anak mereka kemampuan membaca buku suci Islam. Di pihak institusi sekolah, para pendidik diharapkan menawarkan metode pengajaran yang menarik untuk membaca Al-Qur'an sehingga mereka memiliki kemudahan untuk. memperoleh kemampuan. Penelitian ini bertujuan untuk menyelidiki hubungan antara metode pengajaran dan kemampuan siswa untuk membaca Al-Qur'an. Penelitian ini menerapkan penelitian tindakan untuk mengeksplorasi masalah praktis dan menemukan beberapa solusi untuk masalah yang dihadapi. Subjek penelitian adalah 283 siswa kelas VII di Sekolah Menengah Pertama Negeri 2 Porong. Penelitian ini mengumpulkan data melalui: survei, observasi, dan wawancara semi-terstruktur. Temuan menunjukean bahwa kemampuan siswa untuk. membaca Al-Qur'an dapat dikategorikan ke dalam empat tingkatan yaitu: Ibtidä 1, Ibtidā 2, Jayyid, dan Jayyid Jiddan. Keempat kategori tersebut menempatkan siswa berdasarkan kemampuan mereka dalam membaca Al-Qur'an. Menurut korelasi Pearson, ada nilai signifikansi 0,000<0,05, yang berarti ada bubungan linier antara metode pengajaran dan kemampuan siswa untuk membaca Al-Qur'an. Mengikuti basil ini, beberapa metode belajar membaca AlQur'an seperti Iqra, Iqra, Tahqiqu, Talaqqi Mushäfahah, dan CMSA (Cara Mengaji Santri Aktif/cara aktif membaca AlQur'an untuk siswa) berada dalam posisi yang dapat diterapkan untuk meningkatkan kemampuan membaca Al-Qur'an anakanak.

Kata Kunci: Sekolah Ramah Anak, Karakter Religius, Metode Pembelajaran 


\section{INTRODUCTION}

Indonesia, as the largest Muslim country in the world, has a specialized attachment to the Qur'an as the foundation of Muslims. The need to learn to read the Qur'an will always be there and continues to grow. The Qur'an is the word of God that contains Islamic law and human guidelines for achieving a happy life in this world and the hereafter (Munir, 2014). The Qur'an is the proper means of performing for Allah by reading, helping, listening, and listening. Studying the Qur'an is obligatory for every Muslim. Learning is a process of gaining knowledge for each individual. For this reason, the teacher understands the importance of organizing and facilitating students by implementing a local culture-based curriculum on Islamic values (Rosada, Triwoelandari, Supriatna, 2019). Learning the Qur'an is very important to learn because the Qur'an is valid.

The duties and responsibilities of a Muslim in discussing the meaning, memorizing, translating and interpreting, and even practicing it in everyday life. The challenge for teachers teaching Qur'an is to improve students' ability to read what is written in the Qur'an properly, correctly and also efficiently. The Qur'an learning with a child-friendly environment setting by providing a sense of security and comfort (Mandiudza, 2013) can optimize the potential of students' brains (Suyadi, 2019) for students to grow healthy, active, discuss, and socialize with their learning environment. The problem in applying the holy Qur'an pattern is still far from the maximum both in terms of agreed designs and analysis of student learning. The Qur'an learning basic bijaiyah, practice reading, to read perfectly according to the rules related to makhärijul khurüf, shifätul khurüf, tajwid law and being able to practice the complete reading the Q.S. Al-Muzzammil (73; 4) (RI, 2012) "Or add to it, and recite the Qur'an with measured recitation".

Read the trail slowly while paying attention to the letters and the recitation law. A Muslim is obliged to study to the rules; if recite the Qur'an does not pay to attention lafadr, it will change meaning. The habit of reading errors of the Qur'an is a challenge faced by teachers in learning to deliver the ability of students to recite what is written in the Qur'an well, correctly and also smoothly (Otaya \& Husain, Rahmin Talib; Anwar, 2019). The human foundation is commanded by Allah in the Qur'an in Q.S. al Alaq (1-5) "Recite in the name of your Lord who created. Created man from a clinging substance. Recite, and your Lord is the Most Generous. Who taught (human) with the delivery of kalam. Taught man that which he knew not" (Departemen Agama, 2007).

Teaching the Qur'an was required to offer methods that are appropriate to the needs of students; one of them is the Gabriel method. The results showed that learning the Qur'an by using the Gabriel method can improve students' ability to memorize the Qur'an (Athiyah \& Islam, 2019). However, the application of the Gabriel method in learning the Qur'an to students in SMPN 2 Porong has not been able to improve and the ability of students to read the Qur'an following instructions and excellent and correct rules.

The observations of the teaching and learning process on Q.S. Al-Zalzalah is in the process of reviewing, the teacher does not use media or projectors to display Q.S. Al-Zalzalah. The teacher only explains the number of verses, and the student asked to imitate the teacher's reading without explaining the reading law. This kind of learning method certainly confuses students, does not understand the reading law, and finally only mimics the teacher's reading without reading wrong or correct. This kind of routine of reversing the Qur'an does not make students excited and eager to learn but instead diverts students to read the original Qur'an without regard to the rules of reading the correct Qur'an.

Porong SMPN 2 is one of the government referral schools that has implemented childfriendly school programs. An approved child-friendly school is a school that provides and guarantees students learning safely, comfortably, anti-agree, and so on. But in the field, the 
child-friendly school program is still limited to the slogan, the educators in teaching their students are not child friendly. The teaching and learning process methods and learning media used are still monotonous, which helps with the low reading ability of the Qur'an students. Students in Porong SMPN 2 have in planting religion from different families and also study hours are still deficient, which is one hour (40 minutes) in week. schools based on religion that learns the Qur'an can be three hours than discussion and extracurricular activities in the field of the Qur'an such as recitations, calligraphy and so on. Efforts to maximize the ability to reading the Qur'an based on child-friendly in Porong SMPN 2 using the selection method or a right and appropriate way and involvement in learning activities. The Iqra' method can be faster for students who master reading the Qur'an well and efficiently according to the rules (Windarsih, 2019). The steps of the Iqra' method are as follows: 1) creating a learning environment that is fun and not boring, 2) form a study group, 3) design an effective learning framework, 4) help determine the learning needs in the group, 5) students can share learning experiences, and 6 ) assess the results, processes, and effects of learning activities.

To improve the ability of Arabic letters well. The strategy can enhance the skills of reading the Qur'an by up to $90.20 \%$. The success rate of students from the category did not reach the level of 65\%, reading the Qur'an up to 65.08\% (Almenoar, 2010). The results of studying the Qur'an well, actual covering makhärijul letters, the nature of letters, abkämul letters, ahkäm al-maddi wa al-qasr, and ahkäm al-waqf wa al-ibtida . The tahqiq method is proven to be effective in increasing the ability student to reading the Qur'an at the jayyid (fluent reading) level. The stages of learning include 1) grouping students' skills; 2) Qur'an teaching and learning activities; (3) improve the way to read according to the rules; and (4) strengthen and repeat the reading of the Qur'an. Tahqiq learning methods include observing, guiding, memorizing and adjusting, reading, and reminding (Supriyadi \& Julia, 2019). The contribution of the tahqiq method improves the students' ability to read the Qur'an, participates in the aspects of recitation and reading fluency in the Qur'an.

Practically, learning hours of the Qur'an so far are still minimal for discussion of reading and writing the Qur'an only 1 hour or 45 minutes of renewal. Allocation of Qur'an lesson hours added in extracurricular activities, which attended because the ratio of students in SMPN 2 Porong to 853 students is only $20 \%$ of students who can read the Qur'an. 'correctly and adequately, another $80 \%$ can read the Qur'an below standard. The solution to this problem is to increase the allocation of individual for face-to-face learning whose ability to recited the Qur'an was low. This must also be followed by changes in syllabus and textbooks that must be adapted to the needs and needs of students in school. This must also be followed by changes in syllabus and textbooks that must be adapted to the needs and needs of students in school (Zarif, Mohamad, \& Bakar, 2014) by emphasizing learning based on the ability to read the Qur'an properly and correctly according to specified rules (Che Noh \& Kasan, 2019). The Talaqqi and Mushafabah methods who have not yet gotten the level of reading the Qur'an will use the Iqra' method, followed by the high level (fast) reading the Qur'an using the 6month Khatam al-Quran (Hassan \& Zailaini, 2013). The method of habituating listening to the Qur'an for 15 minutes a day, can improve students' memories (Hojjati \& Rahimi, 2014)

There are three principles in learning, according to Ki Hajar Dewantara, namely the system, which is discussing, remembering, and imitating. The arrangement between building students into faithful and dedicated people, physically and spiritually independent, virtuous, intelligent and trained, physically and mentally healthy, being good citizens, responsible for religion, and the welfare of the country (Anshari \& Yutika, 2016). Learning patterns using the system among these are discussed carefully about the child-friendly that teaches students who have the right to learn and express themselves according to their potential. Child-friendly creates a learning environment that provides a sense of security and comfort for students 
(Mandiudza \& Mandiudza, 2013), to develop his talents (Abdullahi, Clement, 2017). The patterns that can be read by students who can read the Qur'an follow students who excel and correctly read in praying and create a generation of loving the Qur'an (Che Noh \& Kasan, 2019). It is crucial to create a friendly learning environment of the Qur'an, so students grow healthy, active, discuss, and socialize with their learning environment. Qur'anic learning correlates with the brain and mind in neuroscience called Islamic Neurology Education. Therefore, an educator can optimize the potential of a student's brain (Suyadi, 2019)

In the digital millennial era, the use of mobile applications in learning the Qur'an is important, meaning that students can learn to read the Qur'an anytime, anywhere and by using application (Sameh, 2013; Chin \& Chen, 2013). Research shows learning programs to read the Qur'an (BBQ) with traditional methods proved to be less effective in implementing Qur'an learning in schools, but e-BBQ is very effective and makes it easy for students to improve their Qur'an reading skills (Hanafi \& Murtadho, 2019). The results showed there was a positive relationship with digital learning of the "Say the Quran" mobile learning application (Mohammad, 2017). Digital learning in Arabic and English with pictures and sounds helps improve student learning outcomes (Fathoni \& Utomo, 2019). The application of learning the Qur'an based on flash animation using students compiling and matching verses makes it a surah of the Qur'an whose composition is intact and correct. This kind of learning media can facilitate the understanding and memory of students in memorizing the verses of the Holy Qur'an (Norhan \& Sanjaya, 2016). For this reason, it takes a pattern of teaching teachers the holy Qur'an at Porong SMPN 2 of the child-friendly with pay attention to cognitivedevelopment and student needs analysis in learning.

\section{METHOD}

This research discusses the problems carried out to find solutions (Cresswell, 2014). The collaborative principle of this study involves researchers, teachers, and students. Researchers consisted of 3 lecturers at the Muhammadiyah University of Sidoarjo with a variety of expertise in the field of learning the Qur'an, the field of design and learning technology, and the field of educational psychology. Two teachers of BTQ (Baca-Tulis Qur'an/Write and Recite the Qur'an) and 283 grade VII students of Porong SMPN 2. Classroom action research determines reflection at each meeting to obtain the expected solution. This action research activity, in addition to the learning process, pre-test, and post-test reading the Qur'an, as well as the training of 20 students with excellent the Qur'an reading skills chosen to assist in the learning process (peer tutors).

In schools, action research refers to a wide variety of evaluative, investigative, and analytical research methods designed to diagnose problems or weaknesses-whether organizational, academic, or instructional — and help educators develop practical solutions to address them quickly and efficiently. Action research may also be applied to programs or educational techniques that are not necessarily experiencing any problems, but that educators simply want to learn more about and improve. The general goal is to create a simple, practical, repeatable process of iterative learning, evaluation, and improvement that leads to increasingly better results for schools, teachers, or programs.

Research at SMPN 2 Porong based on considerations, namely: (1) implementing childfriendly schools and (2) the ability to reading the Qur'an in high school students. Research subjects were 283 from parental education, $20(7 \%)$ undergraduate, $121(43 \%)$ senior high school, 96 (34\%) junior high school and $46(16 \%)$ elementary school.

To collect the data, this research used four kinds of methods:

1. Surveys; in this research, surveys were conducted to see the condition on the field related to the implementation of child friendly Qur'an for children on the sites. 
2. Observations; the observation was performed on the sites to eyewitness the process of child friendly Qur'an applied.

3. Semi-structure interviews; A semi-structured interview was conducted in which the interviewer does not strictly follow a formalized list of questions. Instead, they will ask more open-ended questions, allowing for a discussion with the interviewee rather than a straightforward question and answer format. The given questions are related to the implementation of child friendly Qur'an in the research sites.

4. Pre-test and post-test; A pretest posttest design is an experiment where measurements are taken both before and after a child friendly Qur'an treatments. The design means that the researcher is able to see the effects of this treatments on participants. The correlation of the teaching methods of child-friendly and the ability to read the Qur'an at school then will be analyzed by using Anova. The oneway analysis of variance (ANOVA) is used to determine whether there are any statistically significant differences between the means of two or more independent (unrelated) groups. In this case the group of children in SMP Porong.

The technique of collecting data uses questionnaire an ability student is divided into several categories a, namely the level of Ibtidä’1 (base 1), Ibtidä' 2 (base 2), Jayyid (right), and Jayyid Jiddan (very good). These Level Indicators are presented.

Table 1. The Qur'an Reading Skills Indicator

\begin{tabular}{|c|c|c|}
\hline Level & Reading Skills & Category \\
\hline Ibtidä'1 & $\begin{array}{l}\text { 1. Students do not recognize the Arabic letter } \\
\text { 2. Students acknowledge Arabic letters but } \\
\text { sometimes have difficulty reading. } \\
\text { 3. Students read Arabic with difficulty reading } \\
\text { cursive letters }\end{array}$ & Not fluent \\
\hline Ibtidä2 & $\begin{array}{l}\text { 1. Students can read cursive letters but are still } \\
\text { limited and makhraj is even exchanged } \\
\text { 2. Students learn letters fluently but stammer. } \\
\text { 3. Students can read cursive letters not yet valid } \\
\text { recitation }\end{array}$ & Substandard \\
\hline Jayyid & $\begin{array}{l}\text { 1. Students read cursive letters smoothly and } \\
\text { correctly } \\
\text { 2. Students can pronounce makhraj smoothly } \\
\text { 3. Students understand reading according to } \\
\text { Tajwid }\end{array}$ & Fluent \\
\hline Jayyid Jiddan & $\begin{array}{l}\text { 1. Students read cursive letters smoothly and } \\
\text { correctly } \\
\text { 2. Students pronounce makhraj smoothly } \\
\text { 3. Students learning according to Tajweed and are } \\
\text { able to read the Qur'an with the right rhythm }\end{array}$ & Very Fluent \\
\hline
\end{tabular}

\section{RESULTS AND DISCUSSION}

This discusses the relationship of school-friendly with the ability to read the Qur'an class VII students of Porong SMPN 2. The technique of collecting data uses questionnaire an ability student of reading Qur'an with four levels of categories grouped, namely ibtid $\vec{a} 1$, ibtid $\vec{a}$ 2, jayyid, and jayyid jiddan. The level of grouping the ability to read Qur'an of students through early munāqasah, daily munāqasah, semester munāqasah, and final munāqasab (Sofyan, Hendra, 2019). The implementation of child-friendly al Qur'an learning it can be seen in Figure 1; there is an increase in the ability to read the Qur'an of Grade VII students of Porong SMPN 2. 
ibtidā' '1 level was 28 students (9.9\%), ibtidä' 2 levels were 68 students (24\%), jayyid level was 138 (49\%), and jayyid jiddan level was 49 (17\%).

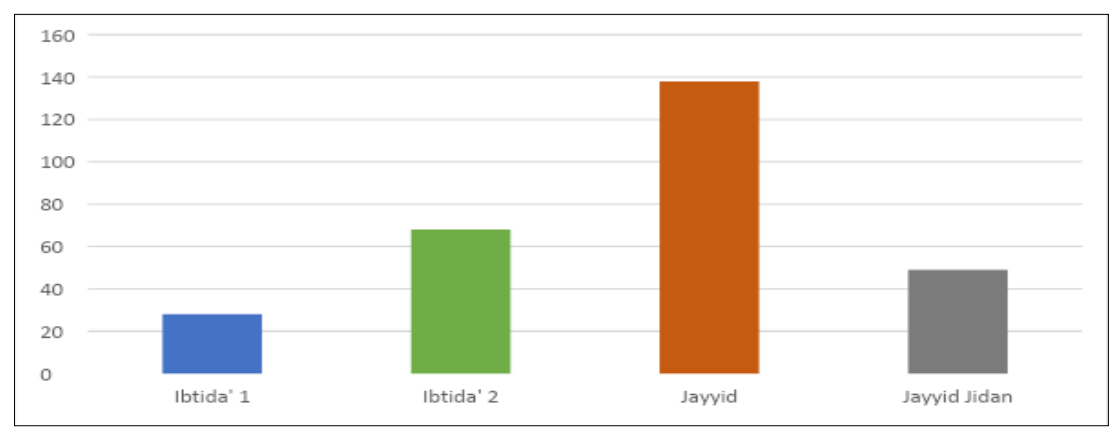

Figure 1. Percentage Reading Skills the Qur'an

From the linearity test in table 2 , Pearson correlation significance value $0.000<0.05$, which means there is a linear relationship between the teaching methods of child-friendly and the ability to read the Qur'an at school. Furthermore, the reading skills column shows 0.789, which means solid used by the teacher and students' reading skills in the Qur'an. Therefore, innovative solutions and methods are needed to improve students' learning abilities. The model considers the Qur'an which contains: 1) reading 2), translating, 3) applying it, 4) memorizing and 5) reading the Qur'an. The teachers need to use various learning strategies according characteristics of their students (Noh, et. al, 2014). Strategies to learn can be a peer tutor for students who can read jayyid jidan to help participants in their level of ability still ibtida' $1 \& 2$. Learning the Qur'an with peer learning of the same method as the CMSA. The CMSA method does not have a shahadah or certificate; the teacher must guide the teacher while helping to teach friends (Sholichin, Saifudin, \& Buana, 2019). The following table 2 and table 3 are the results of statistical analysis that shows the relationship methods instruction and skills reading student.

Table 2. Pearson Correlation

\begin{tabular}{llcc}
\hline & & Method Instruction & Skills Reading \\
\hline Method Instruction & $\begin{array}{l}\text { Pearson } \\
\text { Correlation }\end{array}$ & 1 & $.789^{* *}$ \\
\cline { 2 - 4 } & Sig. (2-tailed) & & .000 \\
\cline { 2 - 4 } & $\mathrm{N}$ & 283 & 283 \\
\hline \multirow{2}{*}{ Skills Reading } & $\begin{array}{l}\text { Pearson } \\
\end{array}$ & $.789^{* *}$ & \\
\cline { 2 - 4 } & Correlation & & \\
\cline { 2 - 4 } & Sig. (2-tailed) & .000 & 283 \\
\cline { 2 - 3 } & $\mathrm{N}$ & 283 & 1 \\
\hline
\end{tabular}

Table 3. Anova

\begin{tabular}{llccccc}
\hline & Model & Sum of Squares & df & Mean Square & F & Sig. \\
\hline \multirow{2}{*}{1} & Regression & 19126.876 & 1 & 19126.876 & 464.791 & $.000^{\mathrm{a}}$ \\
\cline { 2 - 7 } & Residual & 11563.577 & 281 & 41.152 & & \\
\cline { 2 - 7 } & Total & 30690.452 & 282 & & & \\
\hline
\end{tabular}

In Table 3, Anova shows the calculated $F$ value of 464.791 with significance $0.000<$ 0.05 That means significant learning methods with the quality of reading the Qur'an students. Therefore, the teacher must apply the correct teaching methods to help students and quickly memorize the Qur'an (Irlina, 2019). The teacher needs to emphasize character values raising two components. First, being able to reflect on his knowledge and learning experience. Second, students' skills and abilities (Lumpkin \& Achen, 2019). For this reason, the role of the teacher 
needed to create a strong character in which they will continue to grow and develop in society (Khoury, 2017).

Table 4. Coefficients Correlation

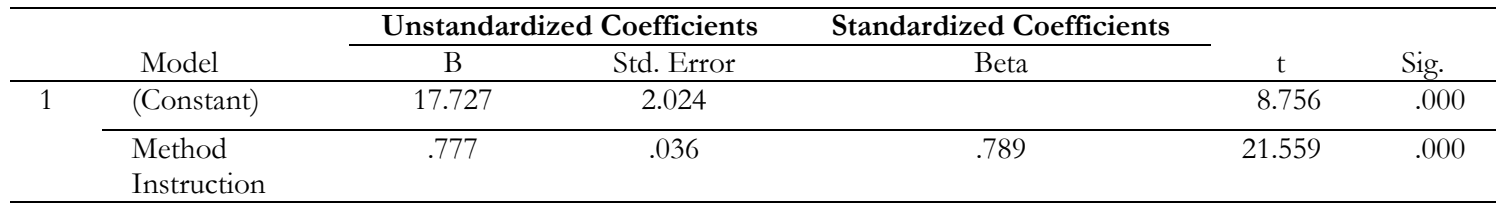

Table 4, The coefficient of estimation variable of teacher method is 0.777 , which means that it represents every $1 \%$ of teacher methods, so the value of students' Qur'an reading skills will increase by 0.777 . Thus, it can be concluded that there is a positive influence between the methods by the teacher and the ability to read the Qur'an of students.

This study aimed exploring learning method for the Qur'an at Porong SMPN 2 which promoted the child-friendly approach. The method also paid attention to cognitivedevelopment and student needs analysis in learning to read the Qur'an. This study found that there is a positive influence of the methods applied by the teacher to the students' ability to read the Qur'an. Their reading skill improvement can be considered as beneficial to learn reading holy book. Reading is the first skill required for Muslim to understand the content of Qur'an that contains Islamic law and human guidelines for achieving a happy life in this world and the hereafter (Munir, 2014).

The method applied in this study had improved students' reading skill for holy book. The method had been designed to comply with a child-friendly environment setting. This was done by providing a sense of security and comfort for children in their learning process (Mandiudza, 2013). Given this circumstance, students were in a position to optimize their potential in terms of their brains (Suyadi, 2019). The method to some extent contributed to students' growth in a healthy, active manner which enable them to discuss, and socialize with their peer and establish positive relationship with their learning environment.

To achieve good result in learning Qur'an, Schools should be able to offer changes in syllabus and textbooks that must be adapted to the students' needs in their learning holy book (Zarif, Mohamad, \& Bakar, 2014). This effort should ensure that the purposes of learning Qur'an should address students' ability to read the Qur'an properly and correctly according to specified rules (Che Noh \& Kasan, 2019). In other words, their compenece in reading Qur'an should be the priority to consider when designing the syllabus.

On the part of the teachers, they must provide the flexibility and opportunity for their students to develop their potential in learning (Mandiudza, 2013). The teachers may establish some learning method like discussing the Qur'an since this method provide opportunities for them to be able constructively share thought and understanding, to facilitate enjoyable learning to the fullest (Suherman, et. al., 2019). Other methods can be applied as long as they promote the effective collaboration among teachers, students, and parents to improve students' Qur'an reading competence in the community (Purnama, Maulida, Sarbini, 2019).

Students' ability to read Qur'an will contribute to their growth and development. Their Qur'an reading ability will be beneficial for their brain and mind. In neuroscience this is called Islamic Neurology Education. Therefore, an educator can optimize the potential of a student's brain (Suyadi, 2019) so they can grow to be faithful and dedicated people, physically and spiritually. This lead them to be a good citizens and a responsible youths for their religion and the country (Anshari \& Yutika, 2016). 


\section{CONCLUSION}

The ability to read the Qur'an for Porong SMPN 2 students is very diverse. For this reason, the required methods are adjusted to the needs and characteristics of students. Given of students who can read the Qur'an below the standard and the minimum amount of teachers who study the Qur'an, strategies to support it can be used; the method of peer tutorial or called the CMSA method can be done with a peer learning system with teacher guidance; the Talaqqi and Mushafahah methods who have not yet gotten the level of reading the Qur'an will use the Iqra' method, followed by the high level (fast) reading the Qur'an using the 6-month Khatam al-Quran; the Tahqiq method is proven to be effective in improving the ability to read the Qur'an by preparing for learning a) grouping students' reading ability in the Qur'an; b) teaching and learning activities of the Qur'an; c) improve the way to read according to the rules; and d) translating and repeating the reading of the Qur'an.

That an academic and school managers Porong SMPN 2 use this strategy as a technique to strengthen and to improve the students' achievement, focusing on discussions about the Qur'an for students is to create a learning environment that is safe, comfortable, and able to develop their students' talents and interests. Electronic BBQ more effective and makes it easy for students to improve their Qur'an reading skills. Electronic collaborative methods can increase the level of participation and creativity, problem-solving skills, decision making, critical thinking, moral values, and self-confidence. It is also necessary to increase hours of learning the Qur'an and the allocation of extracurricular activities related to reading and writing the Qur'an so that it has an impact on improving the ability to read the Qur'an goodly. The importance of creating a child-friendly learning environment prepares students to grow healthy, active, discuss, and socialize with their learning environment.

As suggestions and recommendations, this method can be applied in other places either formally or informally. Moreover, to find out the result of the treatments for different levels, not only for children but also for higher levels to find out the different effect and different point of view.

\section{BIBLIOGRAPHY}

Abdullahi, H. U., Clement, I., Sunusi, S. A. (2017). Child Friendly Schools in Nigeria the Role of the Teacher. International Journal of Education and Evaluation, 3(6), 7-12.

Almenoar, L. (2010). An Introduction to Literary Qur'anic Stylistics. Journal of the American Academy of Special Education Professionals, 70-77.

Anshari, B. I., \& Yutika, M. et. al. (2016). Islamic Education Learning Design Based on System Among. Islamic Education Faces Global Challenges, (September 2016), 105-114.

Athiyah, K., \& Islam, S. (2019). The Innovation of Gabriel Method in Improving Al-Qur'an Memorization of Islamic Elementary School Students. Al Ibtida: Jurnal Pendidikan Guru MI, 6(1), 77-89. https://doi.org/10.24235/al.ibtida.snj.v6i1.3814

Che Noh, M. A., \& Kasan, H. et al. (2019). Strategic Management of Qur'anic Recitation Teaching Among Primary School Teachers in Malaysia. AL-HAYAT: Journal of Islamic Education, 3(1), 1. https://doi.org/10.35723/ajie.v3i1.39

Chin, K. Y., \& Chen, Y. L. (2013). A Mobile Learning Support System for Ubiquitous Learning Environments. Procedia - Social and Behavioral Sciences, 73, 14-21. https://doi.org/10.1016/j.sbspro.2013.02.013

Cresswell, J. W. (2014). Research Design; Qualitative, Quantitative and Mixed Methods Approaches (Fourth Edi). Sage Publication.

Departemen Agama. (2007). Syaamil Al-Qur'an (Terjemah Perkata). Bandung: Sygma. 
Fathoni, K., \& Utomo, A. B. et. al. (2019). Pengembangan Media Pembelajaran Al-Qur'an Berbasis Android di TPQ Al-Falah Semarang. Edu Komputika Journal, 5(2), 110-116. https://doi.org/10.15294/edukomputika.v5i2.27165

Hanafi, Y., \& Murtadho, N. et. al. (2019). Student's and instructor's perception toward the effectiveness of E-BBQ enhances Al-Qur'an reading ability. International Journal of Instruction, 12(3), 51-68. https://doi.org/10.29333/iji.2019.1234a

Hassan, S. S. Bin, \& Zailaini, M. A. Bin. (2013). Khatam Al-Quran in Islamic Education Curriculum in Malaysia. Procedia - Social and Behavioral Sciences, 103, 558-566. https://doi.org/10.1016/j.sbspro.2013.10.373

Hojjati, A., \& Rahimi, A. et al. (2014). Effectiveness of Quran Tune on Memory in children. Procedia-Social and Behavioral Sciences, 114, 283-286. https://doi.org/ 10.1016/j.sbspro.2013.12.699

Irlina, A. (2019). Teaching The Holy Quran to Young Learners (7-12 Years Old). Al-Adrka: Jurnal Ilmiah Pendidikan Guru Madrasah Ibtidaiyah. 9(1), 21-26.

Kementerian Agama. (2012). Al Qur'an Terjemah (T. S. Qur'an, ed.). Bandung: Syaamil Qur'an.

Khoury, R. (2017). Character Education as a Bridge from Elementary to Middle School: A Case Study of Effective Practices and Processes. International Journal of Teacher Leadership, 8(2), 49-67.

Lumpkin, A., \& Achen, R. M. (2019). Leadership Education: Assessment of Learning in A Sport Leadership Course. Journal of Leadership Education, (April). https://doi.org/10.12806/V18/I2/R7

Mandiudza, L. (2013). Child Friendly Schools. Greener Journal of Educational Research, 3(6), 283288.

Mandiudza, L., \& Mandiudza, L. (2013). Child Friendly Schools. 3(6), 283-288.

Mohammad, M. A. H. (2017). Mobile Applications' Impact on Student Performance and Satisfaction. The Turkish Online Journal of Educational Technology, 14(4), 102-112.

Munir, A. S. (2014). Ilmu Tajwid dan Seni Baca Al Qur'an (1 ed.). Jakarta: Rineka Cipta.

Noh, M. A. C., et. al. (2014). The study of quranic teaching and learning: United Kingdom experience. Mediterranean Journal of Social Sciences, 5(16), 313-317. https://doi.org/10.5901/mjss.2014.v5n16p313

Norhan, L., \& Sanjaya, L. (2016). Aplikasi Pembelajaran Menyusun Ayat Sebagai Metode Menghafal Al-Qur'an (Juz 30). Jurnal Online Informatika, 1(2), 87-91. https://doi.org/10.15575/join.v1i2.32

Otaya, L. G., Anwar, H., Husain, R. T. (2019). Estimating the Students' Skill in Reciting and Writing Al qur' an at Faculty of Tarbiyah and Teacher Training IAIN Sultan Amai Gorontalo. Nadwa: Jurnal Pendidikan Islam, 13(1). http://dx.doi.org/10.21580/nw.2019.1.1.3590

Purnama, M. D., Maulida, A., Sarbini, M. (2019). Implementasi Metode Pembelajaran Alquran Bagi Santri Usia Tamyiz di Kuttab Al-Fatih Bantarjati Bogor. Prosiding Al-Hidayah Pendidikan Agama Islam, (1), 179-191. http://dx.doi.org/10.30868/ppai.v1i2B.478

Rosada, S., Triwoelandari., Supriatna, I. (2019). Kelayakan Lembar Kegiatan Siswa Terintegrasi Nilai Agama Pada Mata Pelajaran IPA untuk Mengembangkan Karakter Disiplin. Jurnal Al-Ta'dib, 12(1), 134-147. http://dx.doi.org/10.31332/atdb.v12i1.1323

Sameh, A. (2013). M-learning for Qur'an memorization and teaching its sciences. International Conference Mobile Learning 2013, 183-187. Retrieved from https:// files.eric.ed.gov/fulltext/ED562410.pdf

Sholichin, R., Saifudin, A., \& Buana, V. G. (2019). Dynamics of Use of Methods and Teaching Books in TPQ Learning Under the Ring of LP. Ma' arif in Garum, Blitar. Journal of Development Research, 3(May), 31-36. 
Sofyan, N., Hendra, S. H. (2019). Strategi Pembelajaran Al Quran di Ma'had Al-Jamiah UIN Ar-Raniry Banda Aceh. Edukasi: Jurnal Penelitian Pendidikan Agama dan Keagamaan, 17(1), 70-80. http://dx.doi.org/10.32729/edukasi.v17i1.531

Suherman, U., Budiman, N., Suryana, D., Yudha, E. S., Ahmad, A. B., \& Bin Saper, M. N. (2019). Dimension of peace culture based on Al-quran values. Universal Journal of Educational Research, 7(10), 2171-2178. https://doi.org/10.13189/ujer.2019.071015

Supriyadi, T., \& Julia, J. (2019). The problem of students in reading the Quran: A reflectivecritical treatment through action research. International Journal of Instruction, 12(1), 311-326. https://doi.org/10.29333/iji.2019.12121a

Suyadi, S. (2019). Hybridization of Islamic Education and Neuroscience: Transdisciplinary Studies of 'Aql in the Quran and the Brain in Neuroscience. Dinamika Ilmu, 19(2), 237249. https://doi.org/10.21093/di.v19i2.1601

Windarsih, C. A. (2019). an Implementation of Participative Iqro Method in the Oriented of Al-Quran Education Center on the Purpose of Learning Goal and Objectives for Early Children. Empowerment, 8(1), 25. https://doi.org/10.22460/empowerment.v8i1p2529.1146

Zarif, M. M. M., Mohamad, N., \& Bakar, B. A. (2014). Assessing Quranic reading proficiency in the j-QAF programme. International Education Studies, 7(6), 1-8. https://doi.org/10.5539/ies.v7n6p1 